\title{
Political Economy of Forest Tenure Reform Implementation in Nepal: The Case of Protected Forests
}

\author{
Ambika P. Gautam ${ }^{1}$, Krishna B. Bhujel ${ }^{2}$ and Raju Chbetri ${ }^{3}$ \\ ${ }^{1}$ Kathmandu Forestry College, Kathmandu, Nepal. ${ }^{2}$ Green Solution Nepal, \\ ${ }^{3}$ Ministry of Forest and Soil Conservation, Kathmandu, Nepal. \\ Corresponding author: gautam.ambika@gmail.com
}

\begin{abstract}
Protected forest is a new approach to forest management in Nepal. The programme targets natural forest areas that have high biodiversity, scientific and cultural values but are not covered by the country's protected area network. So far, eight biodiversity-rich natural forest areas and biological corridors, covering a total area of 133,754.8 hectares (ha) are being managed under this regime, and eight other forests, covering a total area of 194,907.9 ha are in the process of being declared as protected forests in the near future. By reviewing existing literature, policy, legislation and management plans, this paper makes a critical analysis of the protected forest management regime from political economy perspective with special focus on the rights offered to local communities, benefit sharing arrangements and tenure security. Mismatch among the law, policy, and practice; lack of legal clarity on the role, responsibility and authority of stakeholders; unclear benefit sharing arrangement; non-clarity about the rights of non-state right holders; and difference in perceptions of tenure arrangements among the stakeholders are some of the specific issues and challenges related to the management of protected forest. Some other contestations relate to division of authority, and benefits sharing between the government and local communities. There is a need to amend the Forest Act 1993 and Forest Regulations 1995, especially to clarify the legal status of the protected forest council, and address the issues of benefit sharing between the central government and local stakeholders. Another important need relates to adopting a flexible policy and implementation approach to address the contextual differences among different protected forest sites located in different physiographic zones across Nepal.
\end{abstract}

Key words: Community forest, Nepal, protected forest, right holders, tenure security

\section{INTRODUCTION}

Protected forest is one of the many forest management modalities that are currently being practiced in Nepal. The Forest Act 1993 defines protected forest as a national forest, which is designated as 'protected' by the government considering its environmental, scientific, and cultural and other significance. Chapter 4, Article 23 of the Forest Act 1993 provides legal basis for the government to declare any part of the national forest as a protected forest. This model of forest management is being implemented by the Department of Forest $(\mathrm{DoF})$ in different ecological zones of the country, since 2002. The programme targets natural forest areas that have high biodiversity, scientific and cultural values but are not covered by the country's protected area network.

The main objective of establishing protected forest is to conserve natural resources and their values, and encourage wise use of those resources for the benefit of local users. The specific objectives are to: (i) enhance biodiversity through rehabilitation of habitats of rare and important species, biological corridors, and wetlands, (ii) achieve self-dependence of forest products through development 
of multi-storey and multiple use of forests, and (iii) enhance local livelihoods through implementation of income generating activities, including market-oriented green enterprises and tourism (Thapa 2011). To achieve these objectives, promotion of alternative energy, such as improved cooking stoves and bio-briquettes, has recently been initiated in some protected forests in Nepal (DoF 2013).

Protected forest is a relatively new approach to forest management in Nepal. Currently, eight forests, covering a total area of 133,754.8 hectares (ha), are under the protected forest regime (MoFSC 2014), and other eight forests, covering a total area of 194,907.9 ha are reportedly in the process of being declared as protected forests. All these forests are key biodiversity areas and important biological corridors.

Different levels of governments and types of non-government agencies for example non-government organisations (NGOs), civil society organisations (CSOs), and local communities, are involved in the management of protected forests. There is, however, a high level of confusion on the roles, responsibilities and authorities of these stakeholders. The current forestry legislation is also not clear about the management strategy to be adopted for protected forests, including utilisation of forest products, roles, responsibility and authority of local stakeholders, for example the protected forest council (PFC), and distribution of the benefits from the forests. These ambiguities have created certain misunderstandings and often conflicts between the government forest agencies and non-government stakeholders, for example the Federation of Community Forest Users Nepal (FECOFUN), and PFC, thereby hampering the effective implementation of the programme. It is also not clear on who actually are the legitimate right holders and targeted beneficiaries of protected forest management. Based on the current practice, the State forestry agencies, communities (PFC, forest user groups - FUGs), and individual users can be considered as the main right holders.

The recently developed Forest Policy 2015 has emphasised the communitybased management of protected forests. However, there is no legal basis or regulatory provision or clear mechanism to implement the provisions stipulated in the policy. The Ministry of Forests and Soil Conservation (MoFSC) has prepared a guideline with clear arrangement of benefit sharing between the government and forest-managing communities. Currently, the Ministry of Finance (MoF) is reviewing the guidelines, and showed its reluctance to endorse it. This mismatch between the MoFSC's proposal and the reluctance of the $\mathrm{MoF}$ on endorsing the guideline has delayed the approval process. Until at least the passage of the guidelines, the governance and management of protected forest will continue to remain top-down, controlled by the government forest entities.

This paper provides an overview of the structure and evolution of the protected forest management regime in Nepal, and makes a critical analysis from the political economy perspectives with focus on the extent of rights offered to local communities, roles of different actors in forest management activities, benefit sharing arrangements and tenure security. It concludes with a discussion of issues and future challenges facing the protected forest regime and provides some 
recommendations for overcoming such challenges. The analysis broadly uses the Institutional Analysis and Development Framework (Ostrom et al. 1999) as the conceptual framework. The findings, which are based on collection and analysis of secondary data and information, are expected to enhance the understanding of protected forest management regime.

The paper is structured into five sections, including the introduction; historical evolution and current status; political economy of reform implementation; key issues and challenges; and conclusions and recommendations.

\section{HISTORICAL AND CURRENT STATUS OF PROTECTED FOREST IN NEPAL}

Implemented in 2002, protected forest is the youngest of all forest management regimes in Nepal. Nepalese government initiated protected forest regime at a time when the priority was on expansion and strengthening of other community based forest management (CBFM) regimes. The government however is not clear on the motive for initiating protected forest regime. Nevertheless, the stated intention behind it seems to be the need for making special arrangement for conservation of natural forest ecosystems, which have significance from environmental, scientific, and cultural point of view, that are not covered by the protected area network.

One of the reasons behind establishment of protected forests can be attributed to the sense of urgency in part of the DoF officials to protect biodiversity that are at risk of being degraded or lost. As the government has been continuously increasing the areas under the protected area networks since 1970s, the DoF leaderships is speculatted to have a sense of fear of bringing the biodiversity-rich big national forests under the protected area network, and thereby losing their territorial jurisdiction of these forests. The fact that many of the established and proposed protected forests are in the midhills, where there is a poor representation of protected area network, substantiates this speculation to some extent. Informal conversations with few forestry officials revealed that the DoF also wanted to be more actively engaged in conservation activities through this programme to meet the perceived expectations of the people.

There are three main legal milestones in terms of the development of protected forest regime in Nepal (Table 1). First, the Forest Act of 1993 (HMGN 1993: Article 23) and Forest Regulations 1995 (HMGN 1995) have provided the legal basis for the MoFSC to declare any part of the national forest, which it considers to have special importance from the environmental, scientific or cultural perspectives. Article 24 of the Act has made the arrangements for preparation and approval of protected forest management plan. The Forest Policy 2015 is another major milestone towards the development of protected forest, which has emphasised on communitybased approach to protected forest management. The Policy stresses on the management of protected forests through a PFC to be established in each site with the participation of local people. Third, the draft protected forest management guideline, which is in the process of approval, generally supports the policy provisions. The draft guidelines include three main tenure related arrangements: (i) adoption of community-based approach 
in the management of protected forests;

(ii) delineation of authorities between the government and local communities; and (iii) proportional distribution of benefits accrued from protected forest between the government and local communities.

Table 1: Key Legal Milestones to the Development of Protected Forest Regimes in Nepal

\begin{tabular}{|c|c|c|}
\hline Year & Event & Main features \\
\hline 1993 & $\begin{array}{l}\text { Formulation of } \\
\text { Forest Act }\end{array}$ & $\begin{array}{l}\text { Chapter 4, Article } 23 \text { of the Act provides legal basis for } \\
\text { establishment of protected forest by the government (i.e. } \\
\text { MoFSC). As per the Act, DoF has to prepare a management } \\
\text { plan and submit it to the Ministry for approval. The } \\
\text { approved plan is to be implemented by concerned district } \\
\text { forest offices (DFOs). There is no provision for people's } \\
\text { participation. }\end{array}$ \\
\hline 1995 & $\begin{array}{l}\text { Formulation of } \\
\text { Forest Regulations }\end{array}$ & $\begin{array}{l}\text { Chapter } 3 \text {, Rule } 24 \text { specifies the subjects to be included } \\
\text { in the protected forest management plan, including use } \\
\text { of forest products. Rule } 25 \text { has made arrangements for } \\
\text { regulating harvest of forest products. There is no provision } \\
\text { for people's participation. }\end{array}$ \\
\hline 2015 & $\begin{array}{l}\text { Development of } \\
\text { Forest Policy }\end{array}$ & $\begin{array}{l}\text { The Policy has put emphasis on community-based } \\
\text { management of protected forest (Working Policy 5). The } \\
\text { Clause } 10.4 \text { of the policy has made provision for equitable } \\
\text { distribution of benefits accrued from all type of forest } \\
\text { management, including protected forest. }\end{array}$ \\
\hline 2016 & $\begin{array}{l}\text { Development of } \\
\text { draft protected } \\
\text { forest guidelines }\end{array}$ & $\begin{array}{l}\text { The guidelines propose to adopt participatory approach } \\
\text { in management of protected forest (similar to other } \\
\text { community-based models that exist in the country). The } \\
\text { guidelines clearly mentioned the rights and responsibilities } \\
\text { of the government forestry agencies and local communities } \\
\text { in management of protected forest, and distribution of } \\
\text { benefits between them. }\end{array}$ \\
\hline
\end{tabular}

The governance of protected forest regime initially was top-down. However, over the years, the governance evolved from a more top-down to a participatory approach. The recent developments indicate that the government is willing to promote the protected forest regime as a communitybased approach. Review of the site-specific forest management plans reveals that the forest regime is progressing slowly towards not only conservation of biodiversity and ecosystems but also enhancement of food security, improvement of local livelihoods and maintenance of socio-ecological resilience of local communities (Table 2). Moreover, there are proposed protected forests that aim to fulfil the objectives (Table 3). The locations of the existing and proposed protected forests are depicted in Figure 1. 
Table 2: Protected Forests in Nepal (MoFSC 2014)

\begin{tabular}{|c|c|c|c|c|}
\hline Forest & $\begin{array}{l}\text { Year } \\
\text { established }\end{array}$ & Size (ha) & $\begin{array}{l}\text { Location/ } \\
\text { ecological } \\
\text { zone }\end{array}$ & Importance \\
\hline Kankre Bihar & 2002 & 175.5 & $\begin{array}{l}\text { Surkhet/ } \\
\text { Siwaliks }\end{array}$ & $\begin{array}{l}\text { Historical; archeological and } \\
\text { biodiversity }\end{array}$ \\
\hline Madhane & 2010 & 13,761 & $\begin{array}{l}\text { Gulmi/ } \\
\text { Midhills }\end{array}$ & $\begin{array}{l}\text { Biodiversity; ecotourism; } \\
\text { serves as a biological corridor } \\
\text { linking Dhorpatan Hunting } \\
\text { Reserve with natural forests of } \\
\text { Pyuthan and Baglung Districts }\end{array}$ \\
\hline Barandabhar & 2011 & 10,466 & $\begin{array}{l}\text { Chitwan/ } \\
\text { Siwaliks }\end{array}$ & $\begin{array}{l}\text { Biological corridor; habitat } \\
\text { for several endangered species; } \\
\text { connects Midhills forests } \\
\text { to Chitwan National Park; } \\
\text { includes important grasslands, } \\
\text { wetland, and forests that } \\
\text { serve as key habitats for tiger, } \\
\text { rhinoceros, deer, monkeys } \\
\text { and several migratory and } \\
\text { resident birds }\end{array}$ \\
\hline \multirow[t]{2}{*}{ Panchase } & \multirow[t]{2}{*}{2011} & \multirow[t]{2}{*}{$5,775.7$} & \multirow[t]{2}{*}{$\begin{array}{l}\text { Kaski, Parbat, } \\
\text { Syangja/ } \\
\text { Midhills }\end{array}$} & $\begin{array}{l}\text { Biodiversity; ecotourism; } \\
\text { religious }\end{array}$ \\
\hline & & & & $\begin{array}{l}\text { Harbors } 589 \text { species of plants, } \\
\text { including } 113 \text { species of } \\
\text { orchids (two endemic); an } \\
\text { important site also from the } \\
\text { cultural, religious and tourism } \\
\text { point of view }\end{array}$ \\
\hline $\begin{array}{l}\text { Laljhadi- } \\
\text { Mohana }\end{array}$ & 2011 & $29,641.7$ & $\begin{array}{l}\text { Kailai, } \\
\text { Kanchanpur/ } \\
\text { Siwaliks and } \\
\text { Tarai }\end{array}$ & $\begin{array}{l}\text { Biological corridor (Nepal- } \\
\text { India); wetland }\end{array}$ \\
\hline Basanta & 2011 & $69,001.2$ & $\begin{array}{l}\text { Kailai/ } \\
\text { Siwaliks and } \\
\text { Tarai }\end{array}$ & $\begin{array}{l}\text { Wildlife habitat and corridor } \\
\text { (Nepal-India) }\end{array}$ \\
\hline Khata & 2011 & 4503.7 & Bardia/Tarai & $\begin{array}{l}\text { Wildlife habitat and corridor } \\
\text { (Nepal-India) }\end{array}$ \\
\hline Dhanushadham & 2012 & 430 & $\begin{array}{l}\text { Dhanusha/ } \\
\text { Tarai }\end{array}$ & $\begin{array}{l}\text { Historical; religious; } \\
\text { biodiversity }\end{array}$ \\
\hline
\end{tabular}


Table 3: Proposed Protected Forests in Nepal (DoF 2016)

\begin{tabular}{|c|c|c|c|c|}
\hline Forest & Size (ha) & $\begin{array}{l}\text { Location } \\
\text { district/ecological } \\
\text { zone }\end{array}$ & Importance & $\begin{array}{l}\text { Current status } \\
\text { of handover } \\
\text { process }\end{array}$ \\
\hline $\begin{array}{l}\text { Tijure-Milke- } \\
\text { Jaljale }\end{array}$ & 58,233 & $\begin{array}{l}\text { Tehrathum, } \\
\text { Sankhuwasabha, } \\
\text { Taplejung/High } \\
\text { Mountains }\end{array}$ & $\begin{array}{l}\text { Biodiversity (especially } \\
\text { Rhododendron spp.); } \\
\text { cultural heritage }\end{array}$ & \multirow{4}{*}{$\begin{array}{l}\text { Management } \\
\text { Plan prepared in } \\
\text { April } 2013 \text { and } \\
\text { submitted to the } \\
\text { MoFSC in July } \\
2014 \text { for formal } \\
\text { decision and } \\
\text { notification in } \\
\text { Nepal Gazette }\end{array}$} \\
\hline Mahabharat & 53,014 & $\begin{array}{l}\text { Dadeldhura/ } \\
\text { Midhills }\end{array}$ & $\begin{array}{l}\text { Important source of } \\
\text { water; natural beauty/ } \\
\text { ecotourism }\end{array}$ & \\
\hline Gaumukhi & 18,038 & Pyuthan/Midhills & $\begin{array}{l}\text { Biodiversity; important } \\
\text { source of water }\end{array}$ & \\
\hline Ramdhuni & 2,054 & Sunsari/Tarai & $\begin{array}{l}\text { Biodiversity; cultural } \\
\text { heritage }\end{array}$ & \\
\hline Resunga & $19,231.35$ & Gulmi/Midhills & $\begin{array}{l}\text { Biodiversity; cultural } \\
\text { heritage; scenic beauty/ } \\
\text { ecotourism }\end{array}$ & \multirow{4}{*}{$\begin{array}{l}\text { Management } \\
\text { Plan prepared } \\
\text { and submitted } \\
\text { by the DoF to } \\
\text { MoFSC in Feb } \\
2015 \text { for formal } \\
\text { decision and } \\
\text { notification in } \\
\text { Nepal Gazette }\end{array}$} \\
\hline $\begin{array}{l}\text { Thaple } \\
\text { Satyawati }\end{array}$ & $37,843.06$ & Gulmi/Midhills & $\begin{array}{l}\text { Biodiversity; cultural } \\
\text { and religious heritage; } \\
\text { scenic beauty/ } \\
\text { ecotourism }\end{array}$ & \\
\hline Rauta & 1,342 & Udaypur & $\begin{array}{l}\text { High altitude } \\
\text { biodiversity } \\
\text { conservation, } \\
\text { Religious Rauta pond } \\
\text { conservation. }\end{array}$ & \\
\hline $\begin{array}{l}\text { Shuvagadi } \\
\text { Surainaka }\end{array}$ & $5,152.49$ & $\begin{array}{l}\text { Kapilvastu/ } \\
\text { Siwaliks }\end{array}$ & $\begin{array}{l}\text { Important biological } \\
\text { corridor }\end{array}$ & \\
\hline
\end{tabular}




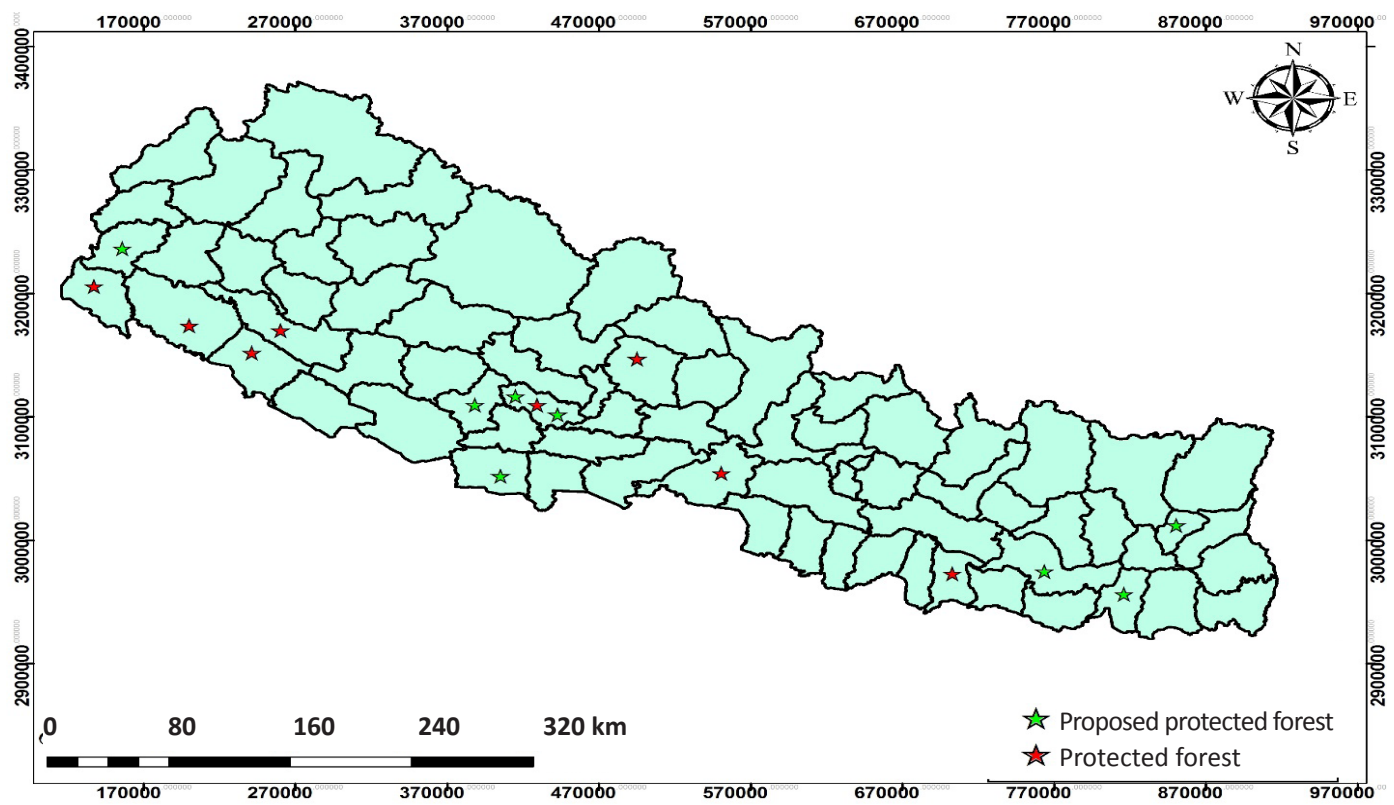

Figure 1: Location of Established and Proposed Protected Forests in Nepal

Each of the protected forest has unique conservation importance. For example, Barandabhar is an important natural forest corridor between Chitwan National Park (CNP) and the Mababharat Mountains, through which wild animals and birds access to refuge at higher altitudes during the monsoon season and other periods of adverse climatic conditions (WWF 2013).

A protected forest is usually divided into three zones: core, fringe, and impact. The core zone is kept strictly for conservation purpose from where only the dead, dying and diseased trees can be removed. Conservation-friendly management applications can be applied in forests and other natural resources located in the fringe zone. The impact zone comprises buffer area around the protection forest, which includes settlements, cultivated land, private forest and national forests. The District Forest Office (DFO) manage the core zone, and existing community forest user groups (CFUGs) manage the fringe zone based on the approved forest operational plans.

Review of management plans of different forests revealed that protected forest can deliver multiple benefits, including improved forest health, environmental condition, biodiversity conservation, and socio-economic conditions (Table 4). 
Table 4: Benefits from Protected Forests

\begin{tabular}{|c|c|}
\hline Category & Major benefits \\
\hline Environmental & $\begin{array}{l}\text { - Soil and watershed conservation } \\
\text { - Restoration of local water sources and improvement in water } \\
\text { - quality } \\
\text { - Increased cover of forest vegetation } \\
\text { - Increased carbon sequestration due to improvement in forest stock }\end{array}$ \\
\hline Biological & $\begin{array}{l}\text { - Improvement in forest regeneration and species conservation } \\
\text { - Improved conservation of wildlife habitats, thereby leading to } \\
\text { increase in populations } \\
\text { - Improvement in biological connectivity } \\
\text { - Improved conservation of biodiversity-rich areas and biodiversity } \\
\text { - Improved conservation of wetlands and wetlands biodiversity in } \\
\text { - Improved conservation of threatened plant species in some cases } \\
\text { (e.g. vijaya sal, satisal in Basanta, Laljhadi) }\end{array}$ \\
\hline Socio-economic & $\begin{array}{l}\text { - Increased production of forest products } \\
\text { - Increased employment opportunities for local people due to } \\
\text { establishment of forest based enterprises, and other income } \\
\text { generating activities. } \\
\text { - Improved prospects for promotion of ecotourism in some areas } \\
\text { (e.g. Kaski) due to enhanced natural scenery in some places } \\
\text { - Positive impact on the health of rural women due to the use of } \\
\text { improved stoves }\end{array}$ \\
\hline
\end{tabular}

\section{POLITICAL ECONOMY OF} TENURE IMPLEMENTATION

A number of government and nongovernment actors are involved in the governance and management of protected forest (Table 5). The Forest Act 1993 vests the authority to prepare and approve a Protected Forest Management Plan (PFMP) with the DoF, and the MoFSC, respectively. The DFO, together with the Protected Forest Management Office (PFMO) established for each protected forest, are responsible to implement the PFMP. Other government actors at the district and local levels include District Coordination Committee (DCC), rural or urban municipalities, District Forestry Sector Coordination Committee (DFSCC), community based FUGs, protected area office (if exists), District Agriculture Development Office, District Livestock Service Office, and District Soil Conservation Office. District Women and Children Office, security agencies, and local units of the Tourism Board are some of the other government actors who are involved in the implementation of PFMP.

A PFC that is established in each site cooperates with the DFO and PFMO in local level policy formulation and implementation, and supports the PFMO in preparation and implementation of the annual plan, and periodic review of the PFMP. The PFC has so far been 
operating in ad-hoc, without a legal basis for its establishment and operation. Local CFUGs, leasehold forest user groups (LFUGs) and other community-based FUGs are supposed to manage their forests, which fall within the boundary of protected forests, under the principles of protected forest management. Other non-government actors include the FECOFUN, forestry and environmental
NGOs, community based organisations (CBOs), media networks, and Federation of Nepalese Chambers of Commerce and Industries (FNCCI). Although the roles and responsibilities of each actor are mentioned in the management plan (Table 5), so far the governance and management of protected forest is largely controlled by the government forest entities, particularly the DFOs.

Table 5: Roles and Responsibilities of Different Actors in Protected Forest Management

\begin{tabular}{|c|c|}
\hline Actor & Role/ responsibility/authority \\
\hline MoFSC & $\begin{array}{l}\text { Approval of Protected Forest Management Plan; monitoring and } \\
\text { evaluation of the plan implementation }\end{array}$ \\
\hline DoF & $\begin{array}{l}\text { Preparation of the PFMP; monitoring and evaluation of the plan } \\
\text { implementation }\end{array}$ \\
\hline $\begin{array}{l}\text { Regional Forest Di- } \\
\text { rectorate }\end{array}$ & $\begin{array}{l}\text { Monitoring and evaluation of the plan implementation; coordination } \\
\text { among concerned stakeholders }\end{array}$ \\
\hline $\mathrm{DFO}$ & $\begin{array}{l}\text { Implementation of the PFMP; coordination with DFSCC and other } \\
\text { relevant district level line agencies; administrative, financial and } \\
\text { personnel management; development of annual plan with support } \\
\text { from the PFMO }\end{array}$ \\
\hline DCC & $\begin{array}{l}\text { Coordination among relevant line agencies in the district; participation } \\
\text { in Regional Monitoring Committee headed by the Regional Director } \\
\text { of Forests }\end{array}$ \\
\hline DFSCC & $\begin{array}{l}\text { Coordination among relevant district level line agencies, civil society, } \\
\text { political parties and other stakeholders; monitoring of the plan } \\
\text { implementation; support to resolution of local level disputes (if any) } \\
\text { review and recommendation for revision of the PFMP, and annual } \\
\text { plan }\end{array}$ \\
\hline PFMO & $\begin{array}{l}\text { Assist the DFO in implementation of the approved management plan } \\
\text { and annual plan; planning of annual activities; support to the DoF } \\
\text { (through DFO) in drafting the PFMP and annual plan; coordination } \\
\text { to raise fund from concerned agencies at the local level }\end{array}$ \\
\hline $\begin{array}{l}\text { Protected Forest } \\
\text { Council }\end{array}$ & $\begin{array}{l}\text { Advise and support to the PFMO in preparation of annual plan, and } \\
\text { periodic review of the plan implementation; Monitoring of the plan } \\
\text { implementation and providing feedback }\end{array}$ \\
\hline $\begin{array}{l}\text { Sector and Ilaka } \\
\text { Forest Offices }\end{array}$ & $\begin{array}{l}\text { Implementation of approved activities at respective (sector or Ilaka) } \\
\text { levels, and submission of progress reports to the DFO; coordination } \\
\text { among the sector or Ilaka level line agencies; monitoring of the plan } \\
\text { implementation by community based FUGs }\end{array}$ \\
\hline
\end{tabular}


District Soil

Conservation Office

District Agriculture

Dev. Office

District Livestock Service Office

District Women \& Children Office

FECOFUN, District Branch

CFUGs, LFUGs, and other communitybased FUGs

VDC/Municipality

NGOS /Cooperatives

Donors
Coordination and partnership in implementation of soil conservation related approved activities; technical supports to other stakeholders for implementing soil conservation activities, conservation farming and water sources conservation

Promotion of agriculture related incomes generating activities at the local level; skill and knowledge to local farmers for commercial production of cash crops; support to agriculture related marketing and improved production

Promotion of improved varieties of livestock and related incomegenerating activities at local level; skill and knowledge to local farmers for livestock farming and commercial production; support to production of forage and fodder at local level and encourage stall feeding; livestock related marketing linkage

Promotion of gender balanced and socially inclusive decision-making at the local level institutions; Support to local people for enhancing their skill and knowledge of gender and social inclusion, and empowering women; support to income-generating activities at local level

Advocacy to ensuring the rights of local FUGs; social mobilisation, awareness raising activities

Management of forests by adopting the principles of protected forest management; implementation of forest-based income-generating activities for pro-poor households; promotion of local users' participation in forest management activities

Implementation of forest, biodiversity and ecotourism based activities in the rural and urban municipality; greenery development activities at local level in partnership with protected forest management office; support in joint planning and implementation; support for local level fund-raising

Social mobilisation and awareness programs related to forest, biodiversity, and environment conservation; promotion of ecotourism; skill and knowledge transfer to the local communities; support local level fund generation and mobilisation

Financial and technical supports for effective implementation of PFMP
Locally elected PFC consisting of 11 to 21 members has been formed at each protected forest site. The PFC membership includes representatives (usually the Chairpersons) of the local (i.e. within the PF) CFUGs and other community based FUGs. In some cases, additional members representing women and other socially disadvantaged groups are included in the PFC to make it more inclusive. The size of the PFC and its composition can vary across different protected forest sites. The proposed guidelines have made provision for a seven-member PFC. 
The DFO (including program implementation unit(s) and Ilaka forest offices), and the relevant sectorial offices support the PFC. Community basedFUGs, local level forestry and environmental NGOs, CBOs, and rural and urban municipalities are also functionally linked to the PFC and implementation units of PFMO. The protected forest programme manager acts as the member-secretary of the PFC. Key agencies involved in implementation of protected forest activities and their relationships are shown in Figure 2.

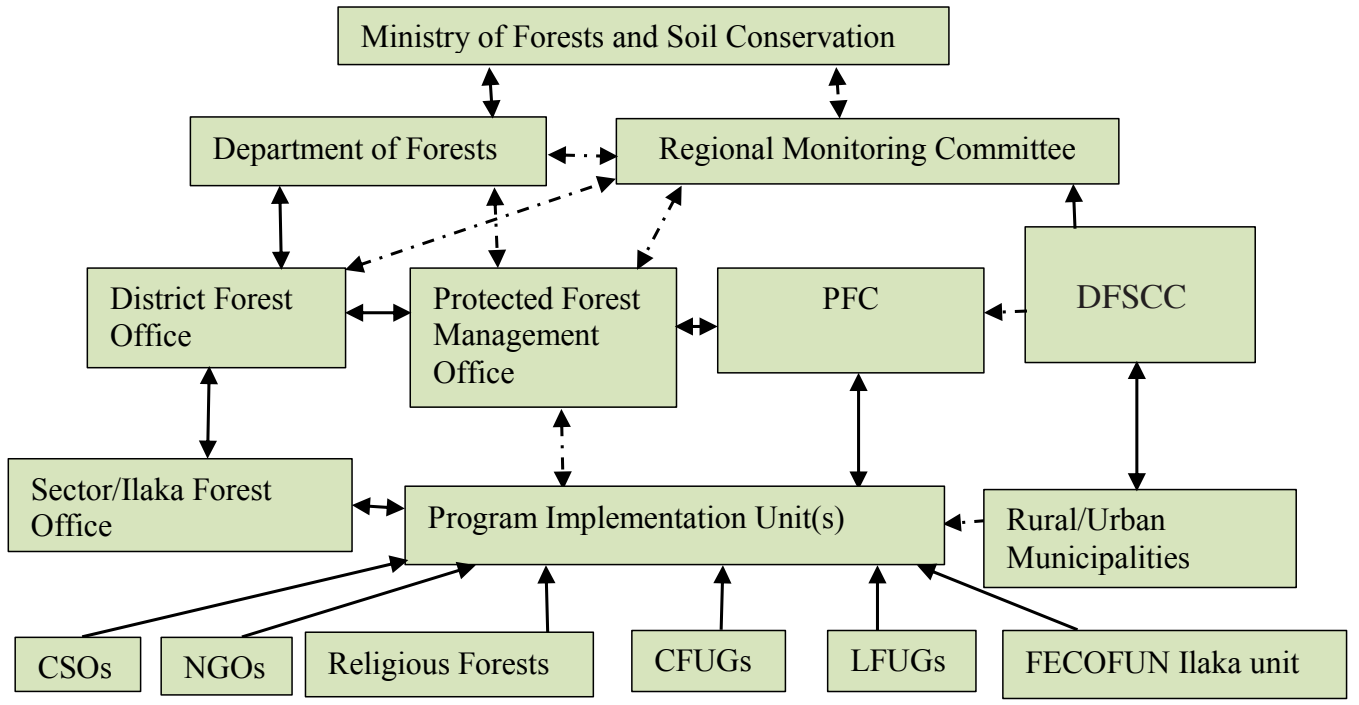

Figure 2: Key Agencies Involved in Implementation of Protected Forest Activities and their Relationships

There are two types of arrangements for coordination and monitoring of protected forest management activities. If the protected forest covers more than one district, a Regional Monitoring Committee headed by the Regional Director of Forests takes the responsibility of coordination and monitoring. The DDC, DFO, District Soil Conservation and Watershed Management Office, media, and regional and district level representatives of the CSOs are members in the committee. If the protected forest area falls within a district, the DFSCC takes the main responsibility of coordination and monitoring.

Protected forest management operations are largely controlled by the DFO.
The PFC plays an advisory role to the Protected Forest Management Office and DFO. Programme Implementation Unit(s) are supposed to implement the approved activities at the local level. The central level decisions are made by the MoFSC and the DoF. The MoFSC has the authority to approve management plan prepared and submitted by the DFO. It implies that the local communities and local institutions will have little role in preparing the PF plan. The Forest Act 1993 and Forest Regulations 1995 do not have clear provision for benefit sharing. However, the draft guidelines have proposed providing 50 per cent of total revenue generated by a protected forest to go back to the PFC fund. There is a little 
clarity on the distribution of the fund under different headings amongst various communities.

All protected forest management activities so far are being implemented on ad-hoc basis due to absence of clear guidelines. There are differences even in the forest management modalities adopted in the Terai, hills and mountains. Sometimes ambiguity in the authority and responsibility between the DFO and protected forest management office creates conflict between these two government units. Conflicts also exist between the DFO and PFC, particularly in matters relating to sharing of the benefits accrued from the management of forest. Till date, the authority of forest products collection, sell and distribution rests with the DFO, and the revenue generated goes directly to the central treasury. This implies that the local communities do not have adequate access to the benefits derived from the forest management. Moreover, implications of new federal structure on the governance of protected forests, is still not clear, except that protection forest management is proposed to be the responsibility of the federal government.

The original design of protected forest regime can be considered as a hybrid of protected area management and comanagement of forests outside protected areas. This has created some confusion both at the policy and implementation levels. Some of the contestations relate to the benefits sharing between the federal government, local communities, and local governments (rural and urban municipalities); roles, responsibilities and authority of CFUGs that existed in the area before the declaration of protected forest; division of responsibilities and authority between the PFC and the DFO; utilisation of forest products from the core area; and compensation to wildlife victims. Some of these issues are likely to be addressed by the proposed guidelines.

Like other forestry regimes, protected forest has the objectives of addressing social inclusion and greater equity along with realising communities' rights, improving livelihoods and promoting conservation. These are generally reflected in the protected forest management plans. However such rights are not fully elaborated in the legal and regulatory documents. The PFC usually includes representatives of women, poor members of the communities, dalits and ethnic groups. Provision of the representation of women and other marginalised social groups is ensured in the decision-making by the implementation units.

Based on analysis of previous research on the common pool resources, Agrawal and Ostrom (2001) identified four categories of property rights that are crucial to understand common-pool resource management, namely: access and withdrawal, management, exclusion, and alienation. In forestry, these rights can be described as the right to withdraw specified forest products from a defined forest area; the right to manage a forested patch, regulate use patterns, and make improvements; the right to determine transfer and exclusion. The right to transfer or alienate refers to sell or lease withdrawal, management, and exclusion rights. We use this approach to compare the property regimes in protected forestry, using information derived from secondary sources (Table 6). 
Table 6: Bundles of Rights and Right Holders in Protected Forest Management

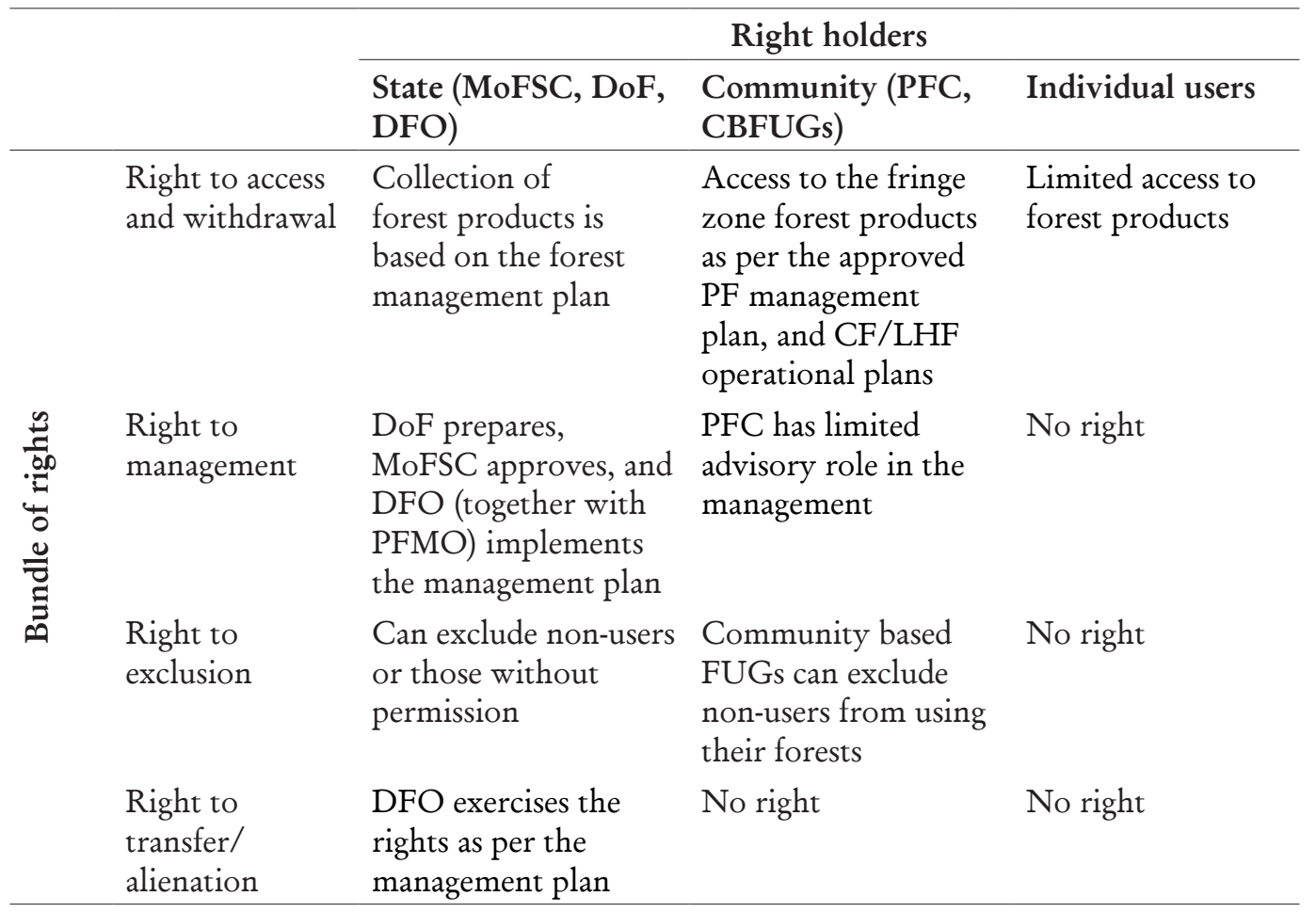

KEYISSUES AND CHALLENGES

\section{Mismatch Among the Laws, Polices, and Practices}

There is confusion on the approach to be adopted in the management of protected forests. The stated objective of the protected forest as per the Forest Act 1993 and Forest Regulations 1995 is conservation of forest areas that have special environmental, scientific, and cultural and other importance. The intention seems to be promoting protected forest regime as an alternative to protected area for conserving key forest biodiversity and ecosystems areas that fall outside of the country's protected area network. The Act has no provision or has not provided space for participation of local communities in the management of protected forests. The Forest Policy 2015, and draft protected forest management guidelines on the other hand, have emphasized for communitybased approach to management of protected forest. This mismatch between the act, policy and proposed guidelines has created confusion in the implementation of the programme. This has also created a doubt on whether the guidelines, which is not clearly supported by the Act and Regulations, will ultimately be approved in its current form. Until this mismatch is addressed, the PFC cannot be functional in achieving its objectives.

\section{Lack of Clarity on the Role, Responsibility and Authority of Different Stakeholders}

One of the major issues in the governance and management of protected forest relates to lack of clarity on the rights, responsibilities, and authority of different 
stakeholders. For example, the Forest Act 1993 and Forest Regulations 1995 are silent about what can be done and what cannot be done in a protected forest. The PFC, which is envisioned by the Forest Policy 2015 to be at the centre of protected forest's institutional arrangement, has no legal basis for its formation, and has no authority for taking management decisions, handling financial matters and benefits sharing. The advisory role that the PFC is playing currently is based on the provision included in individual protected forest management plans, which is not supported by any legislation. Similarly, there is no legal basis for adoption of community based protected forest management as envisioned by the Forest Policy 2015. Unclear rights, responsibilities and authority of different stakeholders, limited consultative processes, and unpredictability of rights arrangements have direct negative effects on the tenure security of local level right holders.

At the local level, the program suffers from unclear responsibilities and authorities of local communities and benefit sharing mechanism. The roles of community based FUGs in the management of protected forest are not clearly mentioned or explained in regulatory instruments and management plans. In addition, poor technical capacities, availability of limited resources, and limited access to administrative and technical services are also common. In this context, due to prevalence of unequal and discriminatory social structures, implementation of tenure reform could be hindered.

\section{Unclear Benefit Arrangements}

Current forestry (or any other) legislations have made no provision for the sharing of benefits accrued from protected forest management. The draft guidelines have proposed equal sharing of revenue generated from implementation of PFMP between the central government and PFC. However, the Ministry of Finance reportedly has strong objection to this proposal due to lack of legal basis for such sharing. Moreover, the guidelines do not seem to have taken into account the ecological differences across the country while proposing the benefit sharing mechanism. Informal discussions with some field level protected forest managers revealed that the PFCs in the Terai and other accessible areas can even be happy with the provision of 100 per cent revenue going to the government treasury, provided they are allowed to use the marginal benefits arising from the differences in the government rate and market rate for forest products (e.g. timber). The same arrangement may not be good for the PFCs that are located in the remote High Mountain areas because the products there (e.g. ecotourism) generally have no such difference in government rate and market rate.

\section{No Clarity on Rights of Non-state Actors}

Among the right holders of protected forest, the government forest agencies have rights to management, and exclusion. As per the current legislation, right to preparation, approval, and implementation of PFMP, 
which determines the rights to access and withdrawal, and right to management, rests on the DoF, MoFSC and DFO, respectively. The DFO can also exclude non-users or those without permission from using the forest. The communitybased CFUGs located in the fringe zone of the protected forest have rights to manage their forest areas as per the principles of protected forest management, and they have rights to access and withdrawal of products from their forests. The user groups' tenure is transferable and perpetual. There is, however, a great deal of confusion among them on what actually the "principles of protected forest management" consist of. The requirement also contradicts with the right of CFUGs to take independent decision about what management approach they like to adopt in their community forests. Moreover, there is no clarity on the access and withdrawal, and management of the core zone of protected forest. Individual users (i.e. local people) can be considered as having limited de facto right to access and withdrawal of forest products. Despite being it a key institutional entity representing the local people, there is no clarity on the rights of the PFC.

\section{Different Perceptions of Tenure Arrangement}

Limited awareness about the program coupled with poor clarity on the rights and responsibility of different stakeholders has led to different perceptions of tenure arrangement among the key stakeholders. Insufficient budgetary allocations; insufficient human resource; limited skills for effective social mobilisation and other support to local communities; and lack of incentive for reform implementation has negatively affected implementation of the program at the meso-level.

\section{Lack of Political Commitment}

There is lack of political commitment to implement the programme, including inadequate institutionalisation; low level of ownership by stakeholders; and insufficient budgetary allocation. Some CSOs, including FECOFUN perceive that the establishment of protected forest is an attempt of the government to bring forests under its control.

\section{Other Challenges}

Getting approval of the proposed protection forest guidelines is a key immediate challenge. Preparation of PFMPs in a participatory and inclusive manner; raising awareness on the advantages of establishing protected forests; reorientation and revision of participatory forestry management plans to match with the principles of protected forest; conflict resolution between the government and the PFC; and addressing economic and livelihoods related expectations of the local communities are some of the pertinent, contemporary challenges.

\section{CONCLUSION AND RECOMMENDATIONS}

The original design of the protected forest can be considered as a hybrid of protected area management and co-management of forests outside protected areas. The authority to prepare and approve a PFMP rests with the DoF, and MoFSC, respectively. DFO, supported by the PFMO and respective sector and Ilaka forest offices, has the main responsibility and authority to implement the PFMP. A PFC that is established in each site plays an advisory role, and the regional level monitoring committee headed by the Regional Director of Forests has mainly monitoring and coordination roles. Local 
community-based FUGs are required to manage their forests that fall within the boundary of protected forest, under the principles and guidelines of protected forest management.

Lack of political commitment to implement the programme, inadequate institutionalisation, and low level of ownership of the key stakeholders partly explains the non-action. Interestingly, these issues have not been addressed by the recent amendment in the Forest Act 1993. Opposition of some CSOs, including FECOFUN, absence of other agencies to systematically lobby in favor of protected forest regime, and possibly tacit hindrance by the Department of National Park and Wildlife Conservation (DNPWC) might have played roles against the protected forest in the amendment of the Act.

There is a need to amend the Forest Act 1993 and Forest Regulations 1995, especially to clarify the legal status of the PFC, and address the issues of benefit sharing among the central government and local stakeholders. The regulations should also address the issues of roles, responsibilities and authority of different stakeholders in the management of protected forests. Another important need relates to adopting a flexible policy and implementation approach to address the contextual differences among different protected forest sites across Nepal. Early approval of the proposed guidelines can address many of the operational issues.

\section{REFERENCES}

Agrawal, A. and Ostrom, E. 2001. Collective Action, Property Rights, and Decentralization in Resource Use in India and Nepal. Politics and Society, 29: 485-514.

DoF. 2013. Hamro Ban 2011/2012 (Annual Progress Report in Nepali). Department of Forest, Government of Nepal, Kathmandu, Nepal.

DoF. 2016. Forestry Database of the Department of Forests. National Forest Division, Department of Forests, Government of Nepal, Kathmandu, Nepal. Unpublished office records available on request (last updated 17 July 2016).

HMGN. 1993. The Forest Act 1993. His Majesty's Government of Nepal, Kathmandu, Nepal.

HMGN. 1995. The Forest Regulation 1995. His Majesty's Government of Nepal, Kathmandu, Nepal.

MoFSC. 2014. Nepal Biodiversity Strategy and Action Plan 2014-2020. Ministry of Forests and Soil Conservation (MoFSC), Government of Nepal, Kathmandu, Nepal.

Ostrom, E., Burger, J., Field, C. B., Norgaard, R. B. and Policansky, D. 1999. Revisiting the Commons: Local Lessons, Global Challenges. Science, 284: 278-282.

Thapa, Y.B. 2011. Summary presentation of protected forests management plans. (unpublished presentation in Nepali).

WWF. 2013. Chitwan-Annapurna Landscape: A Rapid Assessment. Kathmandu: Hariyo Ban Program, WWF Nepal, Nepal. 